\title{
Cudrania cochinchinensis attenuates amyloid $\beta$ protein-mediated microglial activation and promotes glia-related clearance of amyloid $\beta$ protein
}

Chung-Jen Wang ${ }^{1 \dagger}$, Chien-Chih Chen ${ }^{2+}$, Huey-Jen Tsay ${ }^{3}$, Feng-Yi Chiang ${ }^{4}$, Mine-Fong Wu ${ }^{4}$ and Young-Ji Shiao ${ }^{4,5^{*}}$

\begin{abstract}
Background: Microglial inflammation may significantly contribute to the pathology of Alzheimer's disease. To examine the potential of Cudrania cochinchinensis to ameliorate amyloid $\beta$ protein (A $\beta$ )-induced microglia activation, BV-2 microglial cell line, and the ramified microglia in the primary glial mixed cultured were employed.

Results: Lipopolysaccharide (LPS), Interferon- $\gamma($ IFN- $\gamma$ ), fibrillary $A \beta(f A \beta)$, or oligomeric $A \beta(O A \beta)$ were used to activate microglia. LPS and IFN- $\gamma$, but not A $\mathrm{Bs}$, activated BV-2 cells to produce nitric oxide through an increase in inducible nitric oxide synthase (iNOS) expression without significant effects on cell viability of microglia. fA $\beta$, but not oA , enhanced the IFN- $\gamma$-stimulated nitric oxide production and iNOS expression.

The ethanol/water extracts of Cudrania cochinchinensis (CC-EW) and the purified isolated components (i.e. CCA to CCF) effectively reduced the nitric oxide production and iNOS expression stimulated by IFN- $\gamma$ combined with $f A \beta$. On the other hand, oA $\beta$ effectively activated the ramified microglia in mixed glial culture by observing the morphological alteration of the microglia from ramified to amoeboid. CC-EW and CCB effectively prohibit the A mediated morphological change of microglia. Furthermore, CC-EW and CCB effectively decreased A $\beta$ deposition and remained $A \beta$ in the conditioned medium suggesting the effect of CC-EW and CCB on promoting A $\beta$ clearance. Results are expressed as mean \pm S.D. and were analyzed by ANOVA with post-hoc multiple comparisons with a Bonferroni test.
\end{abstract}

Conclusions: The components of Cudrania cochinchinensis including CC-EW and CCB are potential for novel therapeutic intervention for Alzheimer's disease.

Keywords: Neuroinflammation, Cudrania cochinchinensis, Microglia, Mixed glial culture, Amyloid $\beta$, Alzheimer's disease

\section{Background}

Cudrania cochinchinensis is a Chinese folk medicine with anti-inflammation, anti-microbial, and antioxidant properties [1]. A xanthone derivative isolated from $C$. cochinchinesis has been found to inhibit lipopolysaccharide (LPS)-induced nitric oxide production in RAW264.7

\footnotetext{
* Correspondence: yshiao@nricm.edu.tw

${ }^{\dagger}$ Equal contributors

${ }^{4}$ Institute of Biopharmaceutical Science, National Yang-Ming University, Taipei 112, Taiwan

${ }^{5}$ Division of Basic Chinese Medicine, National Research Institute of Chinese Medicine, Taipei 112, Taiwan

Full list of author information is available at the end of the article
}

macrophages [2]. However, the therapeutic potential of C. cochinchinesis on central nervous system (CNS)-related diseases has yet to be studied.

Microglia, the brain-resident macrophages, exhibits several morphological features that distinguish them from peripheral macrophages. These include ramified branches in the steady-state phenotype and the amoeboid morphology of renewed and activated phenotypes [3,4]. Steady-state microglia exhibits a resting-like phenotype, characterized morphologically by extensively ramified processes that continuously monitor its surroundings in the CNS [5]. The property of the activated amoeboid

\section{Biomed Central}

(c) 2013 Wang et al.; licensee BioMed Central Ltd. This is an Open Access article distributed under the terms of the Creative Commons Attribution License (http://creativecommons.org/licenses/by/2.0), which permits unrestricted use, distribution, and reproduction in any medium, provided the original work is properly cited. 
microglia is similar to macrophages. However, the primary determinants of ramified phenotype and amoeboid phenotype of microglia under pathological conditions in the CNS are less well defined and may be different from those of macrophages in the peripheral tissues.

In neurodegenerative diseases, the number of activated microglia increase was observed near the foci of lesions $[6,7]$. The priming of microglia responding to stimuli depends on a set of growth factors, such as macrophage colony-stimulating factor (M-CSF) and IFN- $\gamma[8,9]$. Microglia may exert protective and pathogenic functions in the CNS $[9,10]$ and may exert beneficial and detrimental effects on $\mathrm{AD}$ therapy. $\mathrm{AD}$ pathology is characterized by the accumulation of $A \beta$ containing neuritic plaques [11]. In addition to direct neurotoxicity, oligomeric $A \beta(\mathrm{oA} \beta)$ and fibrillary $A \beta(\mathrm{fA} \beta)$ are known to activate microglia and produce pro-inflammatory mediators; the neurotoxicity may impede the treatment of AD [10]. On the contrary, microglia may protect neurons through the production neurotrophic factors [12], clearing $A \beta$ by phagocytosis $[13,14]$, and degrading $A \beta$ by the secreted enzymes such as insulin degrading enzyme (IDE) [15]. Therefore, it is essential to find an appropriate therapeutic intervention, especially for herbal medicines, aimed at modulating microglia activities from a reduction of the detrimental effects and promotion of a protective role.

We use BV-2 microglial cell line and the primary ramified microglia in the mixed glial culture as an experimental platform. We study the effects of C. cochinchinensis on the therapeutic potential of Alzheimer's disease (AD). The effects on amyloid $\beta$ protein $(A \beta)$-mediated nitric oxide production and inducible nitric oxide synthase (iNOS) expression in the interferon- $\gamma$ (IFN- $\gamma$ ) primed BV-2 cells were studied. On the other hand, the effect of these components on $A \beta$-induced morphological change of steady state ramified microglia in the mixed glial culture and $A \beta$ clearance by microglia were investigated. We found that CC-EW and CCB reduced the nitric oxide production and iNOS expression mediated by fA $\beta$ plus IFN- $\gamma$. Furthermore, the recoveries of the $A \beta$-mediated morphological change of primary microglia and the promotion of microglial clearance of $A \beta$ confirmed the effects of CC-EW and $\mathrm{CCB}$ on the ramified microglia.

\section{Methods}

\section{Reagents}

Medium for cell culture was purchased from Invitrogen (Carlsbad, CA, USA). Mouse anti-actin antibody and synthetic A $\beta 1-42$ were purchased from Millipore (Billerica, MA, USA). Anti-A $\beta 1-17$ antibody (clone 6E10) was from Signet (Dedham, MA). Anti-A A17-24 antibody (clone 4GB) was from Oncogen (San Diego, CA, USA). Anti-Iba-1 antibody was from Abcam (Cambridge, CB4 OWN, NK). Anti-iNOS antibody was from Santa Cruz (Santa Cruz,
California, USA). Enhanced chemiluminescence detection reagents, anti-rabbit and anti-mouse IgG antibody conjugated with horseradish peroxidase were obtained from GE Healthcare (Buckinghamshire, UK). All other reagents were purchased from Sigma (St. Louis, MO, USA) or Merck (Darmstadt, Germany).

\section{Plant material, extraction, and isolation}

The extraction of $C$. cochinchinensis were processed according to the method previously described [2]. Briefly, the air-dried roots of $C$. cochinchinensis were extracted four times with methanol $(\mathrm{MeOH})$ under reflux to give the $\mathrm{MeOH}$ extract. The $\mathrm{MeOH}$ extract was partitioned with an ethyl acetate (EtOAc) and water mixture (1:1) to give the EtOAc extract and the water extract (CC-EW). The EtOAc extract was subjected to silica gel column chromatography eluting with $\mathrm{n}$-hexane: EtOAc/MeOH to give eight fractions. Fractions was further separated by HPLC (Cosmosil 5C18-AR, Nacalai Tesque, Tokyo, Janpan) to obtain CCA to CCF. The structure of each compound (Figure 1a) was elucidated with mass and NMR spectroscopy in comparison to the published data. The purity of each compound was $>98 \%$ as judged by HPLC and ${ }^{1} \mathrm{H}$ NMR.

\section{Cell culture}

BV-2 cells were cultured in Dulbecco's Modified Eagle's Medium (DMEM) containing 10\% fetal bovine serum (FBS). For treatment, the cell medium was replaced with DMEM containing 1\% FBS. Primary cultures of neonatal cortical microglia were prepared from the cerebral cortex of Sprague-Dawley rat pups at postnatal day 5 [16]. Briefly, neonatal day 5 pups were anaesthetized with ether and sacrificed by decapitation. The Institutional Animal Care and Use Committee at the National Research Institute of Chinese Medicine has approved the animal protocol used in our study (IACUC number: 95-P-08 and P-99-18). Primary mixed glial cells were prepared from the cerebral cortex and maintained in DMEM/F12 medium containing 10\% FBS for 3 days. The medium was changed with fresh culture medium and incubated for 2 days. Thereafter, the cells were cultured in Neurobasal medium/B27 supplement for 1 to 10 days.

\section{Preparation and biochemical characterization of $\mathrm{A} \beta$ and $\mathrm{fA} \beta$}

$o A \beta$ and $f A \beta$ were prepared as described $[17,18]$. A diluted solution of $A \beta s$ was spotted onto a mica slide and scanned using an Agilent 5400 atomic force microscope (Molecular Imaging Corporation, Tempe, AZ) as described previously [19]. Figure 1(b) shows the morphology of the prepared $\mathrm{oA} \beta$ and $\mathrm{fA} \beta$. 
a<smiles>CC(C)=CCc1c(O)cc(O)c2c(=O)c3cccc(O)c3oc12</smiles>

1,3,5-trihydroxy-4prenylxanthone<smiles>O=C1c2c(O)cc(O)cc2OC(c2ccc(O)cc2)C1O</smiles>

CCD Quercetin<smiles>CC(C)=CCc1c(O)cc(O)c2c(=O)c3cc(O)ccc3oc12</smiles>

1,3,7-trihydroxy-4prenylxanthone<smiles>O=C1c2c(O)cc(O)cc2OC(c2ccc(O)cc2)C1O</smiles>

CCC

3,4',5,7-tetrahydroxyflavanone<smiles>O=C1CC(O)(c2ccc(O)cc2O)OC2C=C(O)CC(O)C12</smiles>

CCE

2,4',6',7-tetrahydroxy-5methoxyflavanone<smiles>O=C1c2c(O)cc(O)cc2OC(c2ccc(O)cc2O)C1O</smiles>

CCF

2',3,4',5,7-pentahydroxyflavanone

b

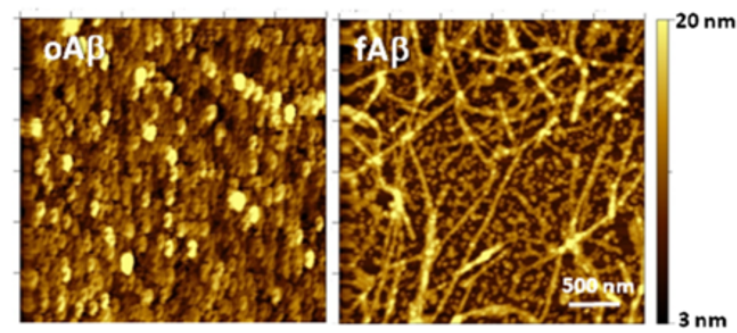

Figure 1 The structure of the compounds and the amyloid peptides used in this study. (a) The structure and chemical name of the compounds isolated from C. cochinchinesis. (b) The representing images of the conformation of the prepared A $\beta$ aggregates.

\section{Measurement of nitrite}

Nitrite content (nitric oxide release) was measured by incubating culture medium with an equal volume of Griess reagent $(0.05 \% \mathrm{~N}$-(1-naphthyl)-ethylene-diamine dihydrochloride, $0.5 \%$ sulfanilamide, and $1.25 \%$ phosphoric acid). After incubation, the optical density was detected at a wavelength of $540 \mathrm{~nm}$ using a microplate reader with $\mathrm{NaNO}_{2}$ as standard.

\section{MTT assay}

The reduction of 3-[4,5-dimethylthiazol-2-yl]-2,5-diphenyltetrazolium bromide (MTT) was used to evaluate cell viability. Cells were incubated with $0.5 \mathrm{mg} / \mathrm{ml}$ MTT for $1 \mathrm{~h}$. The formazan particles were dissolved with DMSO. $\mathrm{OD}_{600 \mathrm{~nm}}$ was measured using an ELISA reader.

\section{Immunoblotting}

After treatment, culture media were collected and cells were washed with ice-cold PBS three times. Cells were harvested in lysis buffer (50 mM Hepes pH7.5, $2.5 \mathrm{mM}$ EDTA, $1 \mathrm{mM}$ phenylmethylsulfonyl fluoride, $5 \mu \mathrm{g} / \mathrm{ml}$ aprotinin, and $10 \mu \mathrm{g} / \mathrm{ml}$ leupeptin) and cell lysates were prepared. Equal protein amounts of cell lysate and an equal volume of culture medium were subjected to SDSpolyacrylamide gel electrophoresis and immunoblotting. Fujifilm LAS-3000 (Tokyo, Japan) was used to detect and quantify the immunoreactive protein.

\section{Immunocytochemistry}

Treated cells were fixed with $4 \%$ paraformaldehyde (in PBS) at room temperature for $15 \mathrm{~min}$ and permeabilized with $0.5 \%$ Triton X-100 (in PBS) for 10 min. Cells were blocked with $10 \%$ normal donkey serum (in PBS containing $0.5 \%$ bovine serum albumin, BSA) at room temperature for $2 \mathrm{~h}$. Cells were treated to detect microglia and its activation using goat anti-Iba-1 and mouse anti-iNOS, respectively. Donkey anti-rabbit IgG or anti-goat IgG conjugated with cy5 and donkey anti-mouse IgG conjugated with fluorescein were used as secondary antibodies. For the study of $A \beta$ deposition, anti- $A \beta$ monoclonal antibody $4 \mathrm{G} 8$ and donkey anti-mouse IgG antibody 
conjugated with fluorescein were used as first and secondary antibodies, respectively.

\section{Morphological quantification}

Metamorph (software) was employed to calculate cell area and convex area of microglia. Form factor was calculated by dividing cell area with convex area, which was described before [20].

\section{Quantification of $A \beta 1-42$ in cells and culture medium}

After treatment, culture media and cells were collected separately and subjected to determine the levels of $A \beta 1$ 42 using assay kits (Invitrogen, KHB3442). The detailed experiments were performed according to the manufacturer's protocol. The conditioned medium was added to assay wells pre-coated with anti-amyloid antibody and incubated with detection antibody at room temperature for $3 \mathrm{~h}$. After wash, the wells were incubated with hourse radish peroxidase anti-rabbit antibody for $30 \mathrm{~min}$ at romm temperature. The wells were then incubated with stabilized chromogen for $30 \mathrm{~min}$ at romm temperature. After adding stop solution, the wells were read at $450 \mathrm{~nm}$.

\section{Statistical analysis}

Results are expressed as mean \pm S.D. and were analyzed by ANOVA with post-hoc multiple comparisons with a Bonferroni test.

\section{Results}

The nitric oxide production induced by LPS, IFN- $\gamma$, and IFN- $\gamma$ combined with $f A \beta$ in BV- 2 cells culture

To determine the inflammatory potential of BV-2 cells, nitric oxide production was assayed after BV-2 cells were a
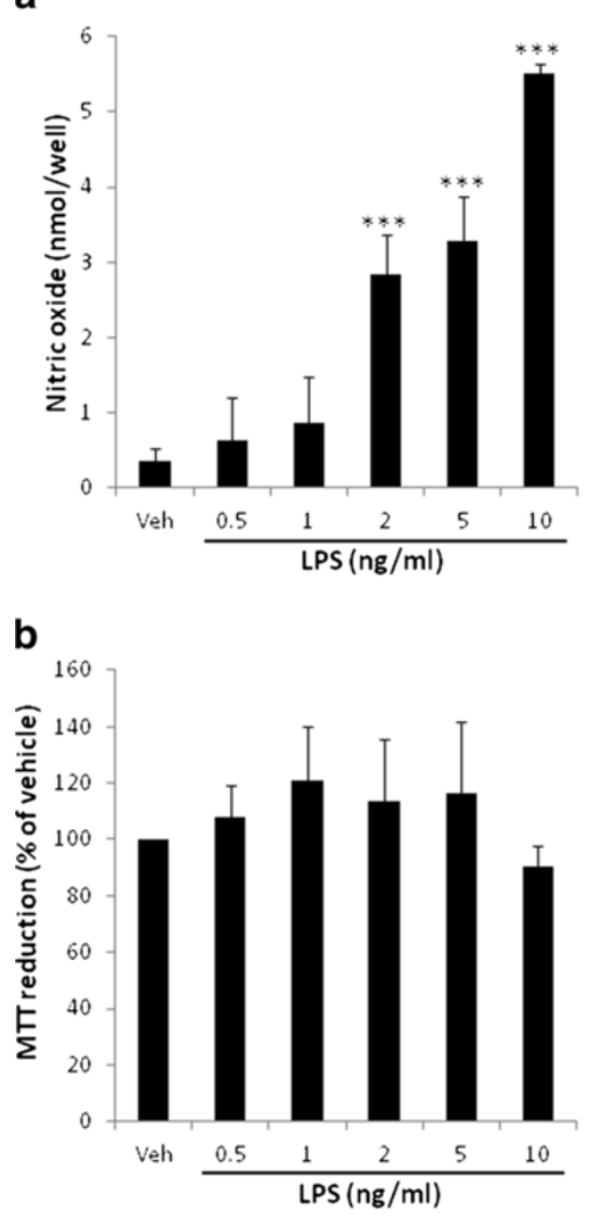

C

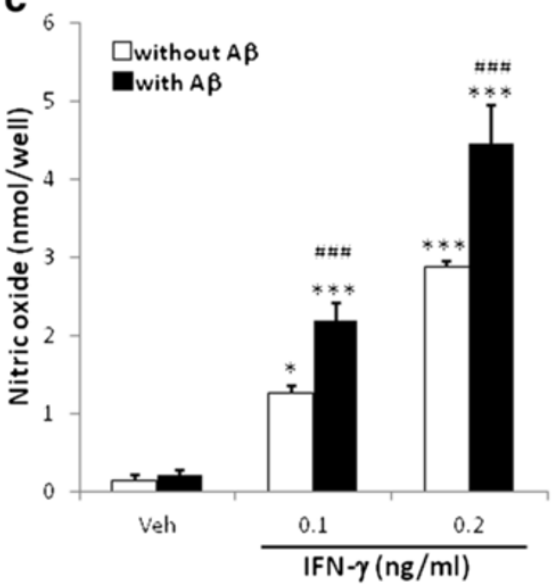

d

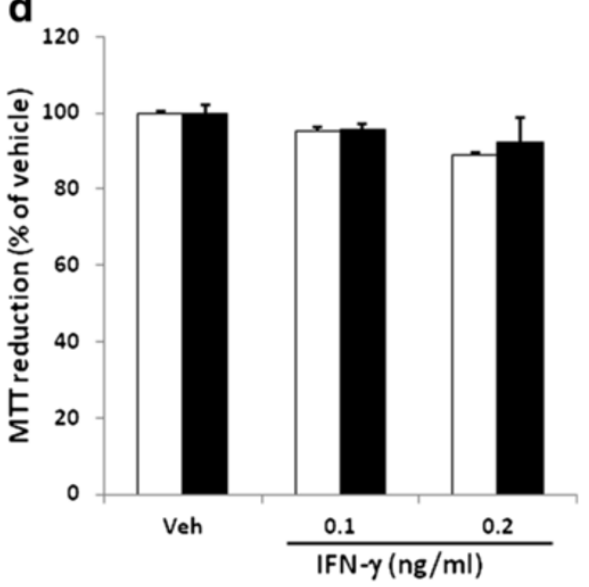

Figure 2 Effect of LPS, IFN- $\gamma$, and IFN- $\gamma+f A \beta$ on nitric oxide production in BV- 2 cells. BV- 2 cells were treated with indicated concentrations of LPS $(\mathbf{a}, \mathbf{b})$ or vehicle, 0.1 and $0.2 \mathrm{ng} / \mathrm{ml}$ IFN- $\gamma$ alone, vehicle or FN- $-1+1 \mu \mathrm{M} \mathrm{fA \beta}(\mathbf{c}, \mathbf{d})$, for $24 \mathrm{~h} . \mathbf{( a ,} \mathbf{c})$ After treatment, cultured medium was collected and the nitrite content was determined. $(\mathbf{b}, \mathbf{d})$ The cell viability of the treated cells was assayed by MTT reduction. Results are means \pm S.D. from three independent experiments. Significant differences between cells treated with vehicle (Veh) and LPS or IFN- $\gamma$ is indicated by *, $p<0.05$, ***, $p<0.001$. Significant differences between the cells treated with IFN- $\gamma$ alone and IFN- $\gamma$ combined with fA $\beta$ are indicated by $\# \# \#, p<0.001$. 
activated by different stimuli. LPS at 2 and $10 \mathrm{ng} / \mathrm{ml}$ stimulate BV-2 to produce $2.83 \pm 0.54$ and $5.52 \pm 0.12 \mathrm{nmol} /$ well nitric oxide, respectively, without significantly affect the cell viability (Figure $2 \mathrm{a}, \mathrm{b}$ ). IFN- $\gamma$ at 0.1 and $0.2 \mathrm{ng} / \mathrm{ml} \mathrm{stim-}$ ulates BV-2 to produce $1.27 \pm 0.10$ and $2.88 \pm 0.07 \mathrm{nmol} /$ well nitric oxide, respectively. As combined with $1 \mu \mathrm{M}$ $\mathrm{fA} \beta$, the production of 0.1 and $0.2 \mathrm{ng} / \mathrm{ml}$ IFN- $\gamma$-stimulated nitric oxide productions were increased to $2.20 \pm 0.22$ and $4.46 \pm 0.49 \mathrm{nmol} /$ well, respectively (Figure 2c). The cell viability is also not affected by IFN- $\gamma$ (Figure $2 \mathrm{~d}$ ). However, $\mathrm{oA} \beta$ failed to enhance the IFN- $\gamma$-stimulated production of nitric oxide (data not shown).

The effects of CC-EW and the compounds, CCA to CCF, on nitric oxide production induced by IFN $-\gamma$ alone or combined with $\mathrm{fA} \beta$ in BV-2 cells culture

To determine the anti-inflammatory effects of CC-EW, IFN- $\gamma(0.2 \mathrm{ng} / \mathrm{ml})$ alone or combined with fA $\beta(1 \mu \mathrm{M})$ were used as stimuli. CC-EW $(20 \mu \mathrm{g} / \mathrm{ml})$ reduced the nitric oxide production mediated by IFN- $\gamma$ alone and combined with $\mathrm{fA} \beta$ to $26.95 \pm 4.79 \%$ and $53.79 \pm 7.68 \%$ of the vehicle treated control cells, respectively (Figure $3 \mathrm{a}$ ). The $\mathrm{IC}_{50}$ of CC-EW on the cells stimulated with IFN- $\gamma$ alone and combined with $\mathrm{fA} \beta$ was $58.28 \pm 6.72$ and $12.83 \pm 3.36 \mu \mathrm{g} / \mathrm{ml}$, respectively (Table 1), to suggest that CC-EW possess a higher inhibitory activity specifically to the stimulation by IFN- $\gamma$ combined with fA $\beta$ than that by IFN- $\gamma$ alone. On the contrary, CC-EW did not inhibit the stimulation by LPS $(10 \mu \mathrm{g} / \mathrm{ml})$ (Figure 3e). On the other hand, CC-EW in the concentration below $100 \mu \mathrm{g} / \mathrm{ml}$ did not significantly affect the viability of BV-2 cells (Figure 3d, f).

Six pure compounds isolated from CC-EW were also subjected to the inhibition assay of nitric oxide production stimulated by IFN- $\gamma$ plus $\mathrm{fA} \beta$. The results showed that $20 \mu \mathrm{M}$ of CCA, CCB, CCC, CCD, CCE, and CCF inhibit nitric oxide production to $66.67 \pm 17.54,46.67 \pm$ $6.67,57,78 \pm 4.44,66.67 \pm 5.76,66.67 \pm 8.07$, and $64.64 \pm$ $6.67 \%$ of the vehicle treated control cells, respectively
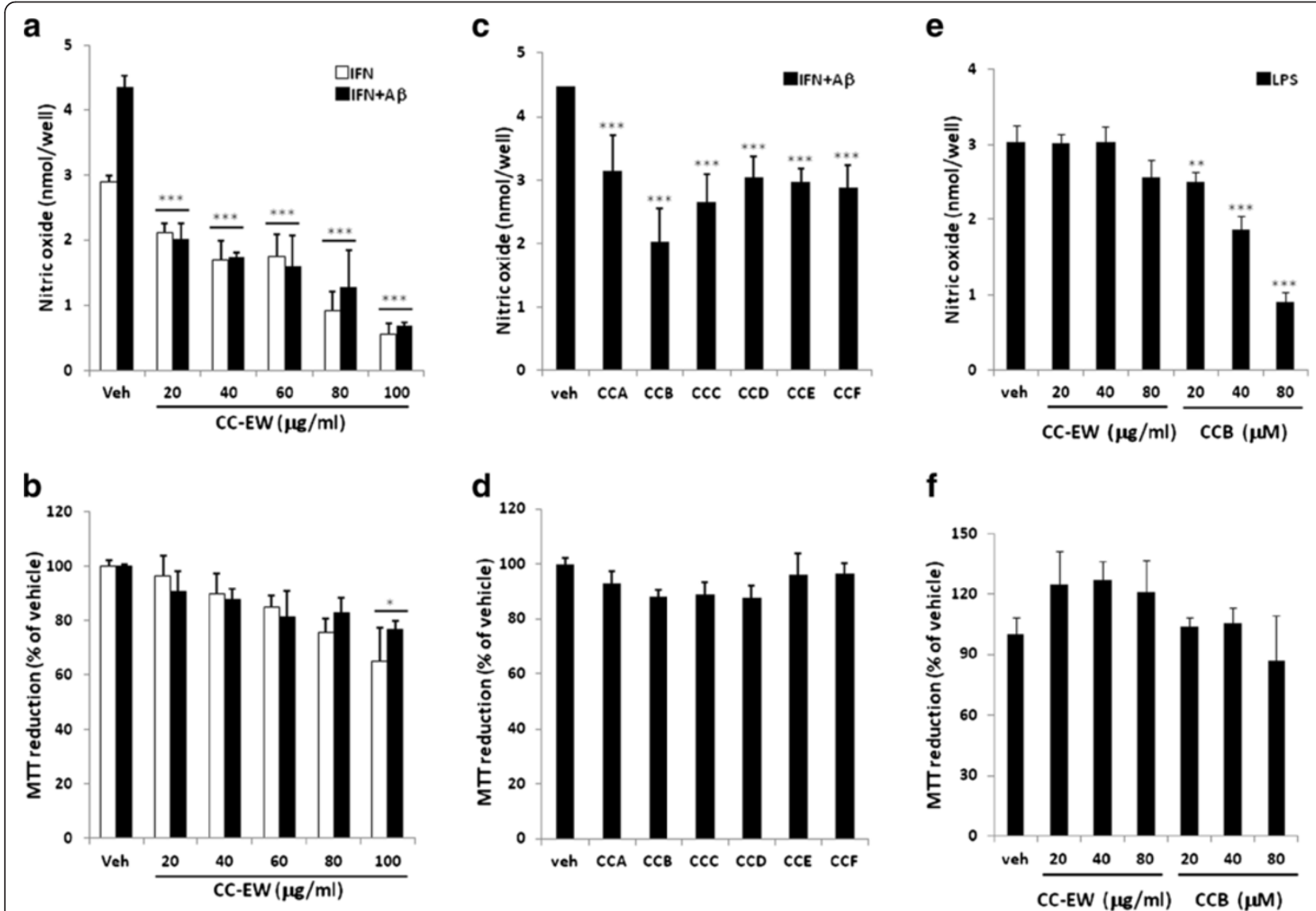

Figure 3 Effect of Cudrania cochinchinensis on nitric oxide production induced by IFN- $\gamma, f A \beta$ and LPS in BV-2 cells. BV-2 cells were treated with indicated concentration of CC-EW (a, $\mathbf{b}, \mathbf{e}, \mathbf{f}), 20 \mu \mathrm{M}$ of CCA to CCF $(\mathbf{c}$, $\mathbf{d})$ or indicated concentration of CCB for 2 h, and then

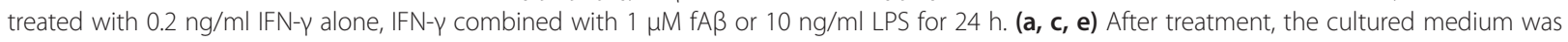
collected and the nitrite content was determined. (b, $\mathbf{d}, \mathbf{f})$ The cell viability of the treated cells was assayed by MTT reduction. Results are means \pm S.D. from three independent experiments. Significant differences between the cells treated with vehicle (Veh) and CC-EW or the compound, CCA to CCF, are indicated by ***, $p<0.001$. 
Table 1 The IC $\mathrm{C}_{50}$ of CC-EW and CCB for A $\beta$-mediated changes on microglia

\begin{tabular}{|c|c|c|c|c|c|}
\hline \multirow[t]{2}{*}{ Stimuli } & \multirow[t]{2}{*}{ Component } & \multicolumn{4}{|c|}{$\mathrm{IC}_{50}(\mu \mathrm{g} / \mathrm{ml} \text { or } \mu \mathrm{M})^{\mathrm{a}}$} \\
\hline & & Nitric oxide & iNOS expression & Form factor & $A \beta$ deposition \\
\hline IFN- $\gamma$ & CC-EW & $58.28 \pm 6.73$ & nd & nd & nd \\
\hline \multirow[t]{2}{*}{$\mathrm{IFN}-\gamma+\mathrm{A} \beta$} & CC-EW & $12.83 \pm 3.36$ & $40.83 \pm 5.66$ & $30.00 \pm 3.65$ & $32.67 \pm 2.69$ \\
\hline & $C C B$ & $11.01 \pm 1.02$ & $11.37 \pm 1.63$ & $10.02 \pm 2.11$ & $17.82 \pm 1.78$ \\
\hline
\end{tabular}

a. The unit for $\mathrm{IC}^{50}$ is $\mu \mathrm{g} / \mathrm{ml}$ for CC-EW and $\mu \mathrm{M}$ for CCB.

nd means not determined.

(Figure 3b). The results indicated that $\mathrm{CCB}$ is the most effective compounds and its $\mathrm{IC}_{50}$ is calculated as $11.01 \pm$ $1.02 \mu \mathrm{M}$ (Table 1). CCB also possesses inhibitory activity to stimulation by LPS (Figure 3e). All six compounds did not significantly affect the viability of BV-2 cells (Figure 3d, f).

\section{The effects of CC-EW and CCB on the iNOS expression induced by IFN- $\gamma$ alone or combined with $\mathrm{A} A \beta$ in $B V-2$ cells culture}

Nitric oxide is produced by the activity of iNOS, which is expressed in activated inflammatory cells. To determine whether the modulation of nitric oxide production was attributable to the level of iNOS expression, the immunocytochemistry using anti-iNOS antibody was performed to detect iNOS expression in the treated BV2 cells. IFN- $\gamma$ significantly increases the percentage of iNOS-positive BV-2 cells (Figure $4 \mathrm{a}, \mathrm{b}$ ). fA $\beta$ did not increase the percentage of iNOS-positive BV-2 cells. However, it significantly enhances IFN- $\gamma$-induced iNOS expression. Alternatively, the positive control, LPS, extensively increase the percentage of iNOS-positive BV-2 cells. Use of IFN- $\gamma$ combined with fA $\beta$ as stimuli, CCEW and CCB significantly inhibits iNOS expression with $\mathrm{IC}_{50}$ at $40.83 \pm 5.66 \mu \mathrm{g} / \mathrm{ml}$ and $11.37 \pm 1.63 \mu \mathrm{M}$, respectively (Figure 4; Table 1). The results indicated that CCB is better than CC-EW on inhibiting the iNOS expression. The iNOS level was also determined from immunoblotting. The results show that IFN- $\gamma$ combined with $f A \beta$ induced a significantly higher amount of iNOS expression than that induced by IFN- $\gamma$ alone. Although the level is not as high as that stimulated by the positive control LPS. CC-EW reduced the iNOS expression induced by IFN- $\gamma$ combined with $\mathrm{fA} \beta$ to $35.24 \pm 0.05 \%$ of that induced by IFN- $\gamma$ plus fA $\beta$. The results indicated that CC-EW significantly reduced the iNOS expression induced by IFN- $\gamma$ combined with fA $\beta$.

The effects of LPS, IFN- $\gamma$, and $o A \beta$ on morphological change of the ramified microglia in mixed glial culture The morphological change of the ramified microglia in the primary mixed glial culture was further employed to examine the effect of $A \beta$ on microglia activation. The microglia co-cultured with astrocyte displayed ramified processes with a small cell body and several long processes.
The ramified morphology was altered to amoeboid as the cell was activated by $10 \mathrm{ng} / \mathrm{ml}$ LPS, $0.5 \mathrm{ng} / \mathrm{ml}$ IFN- $\gamma$ (IFN), or 1 to $10 \mu \mathrm{M}$ oA $\beta$ (Figure $5 \mathrm{a}$ ). To quantify the morphological alteration of microglia, the form factor of single cell was calculated as described in the Method section. The results showed that LPS and IFN- $\gamma$ significantly increased the form factor of microglia from $0.29 \pm 0.07$ to $0.71 \pm 0.04$ and $0.62 \pm 0.02$, respectively (Figure $5 \mathrm{~b}$ ). oA $\beta$, at 1 and $5 \mu \mathrm{M}$, increase the form factor of microglia from $0.29 \pm$ 0.07 to $0.42 \pm 0.10$ and $0.77 \pm 0.16$, respectively. On the other hand, the morphology of astrocyte was altered by LPS, IFN- $\gamma$ and oA $\beta$ from ramified to broaden processes or spreading lamella shape (Figure $5 \mathrm{a}$ ).

CC-EW and CCB inhibited the morphological alteration induced by $\mathrm{oA} \beta$ and the $\mathrm{IC}_{50}$ is $30.00 \pm 3.65 \mu \mathrm{g} / \mathrm{ml}$ and $10.02 \pm 2.11 \mu \mathrm{M}$, respectively (Figure 6a, 6b; Table 1). On the other hand, CC-EW and CCB did not significantly affect the morphology of astrocytes (Figure 6a).

\section{The effect of CC-EW and CCB on deposit and soluble oA $\beta$} in mixed glial culture

The effect of CC-EW and CCB on recovering morphological alteration may be attributable to that CC-EW and $\mathrm{CCB}$ promote oA $\beta$ clearance by microglia and/or astrocytes. This hypothesis was verified by detecting the $A \beta$ deposition on cells and the remaining soluble $A \beta$ in the conditioned medium. Therefore, the immunostaining of the deposit $A \beta$ on cells was performed and the soluble $A \beta$ was determined by ELISA assay. The results showed that the $A \beta$ deposition was significantly reduced by $\mathrm{CC}$-EW and $\mathrm{CCB}$, and $\mathrm{IC}_{50}$ is $32.67 \pm 2.69 \mu \mathrm{g} / \mathrm{ml}$ and $17.82 \pm 1.78 \mu \mathrm{M}$, respectively (Figure $6 \mathrm{c}$, Table 1 ). The remained soluble $A \beta$ in the conditioned medium was also significantly reduced by CC-EW and CCB (Figure 6d).

\section{Discussion}

The pro-inflammatory activation of microglia is one of the major events in the pathology of AD. However, the activation of microglia has been suggested to help clear $\mathrm{A} \beta$ by either promoting phagocytosis or enzymatic degradation [13-15] and to secret neurotrophic factors [12]. In another word, microglia could exert beneficial and detrimental effects on AD therapy $[8,10]$. Accordingly, some studies have been conducted to develop herbal medicines to switch microglial phenotype from detrimental to 

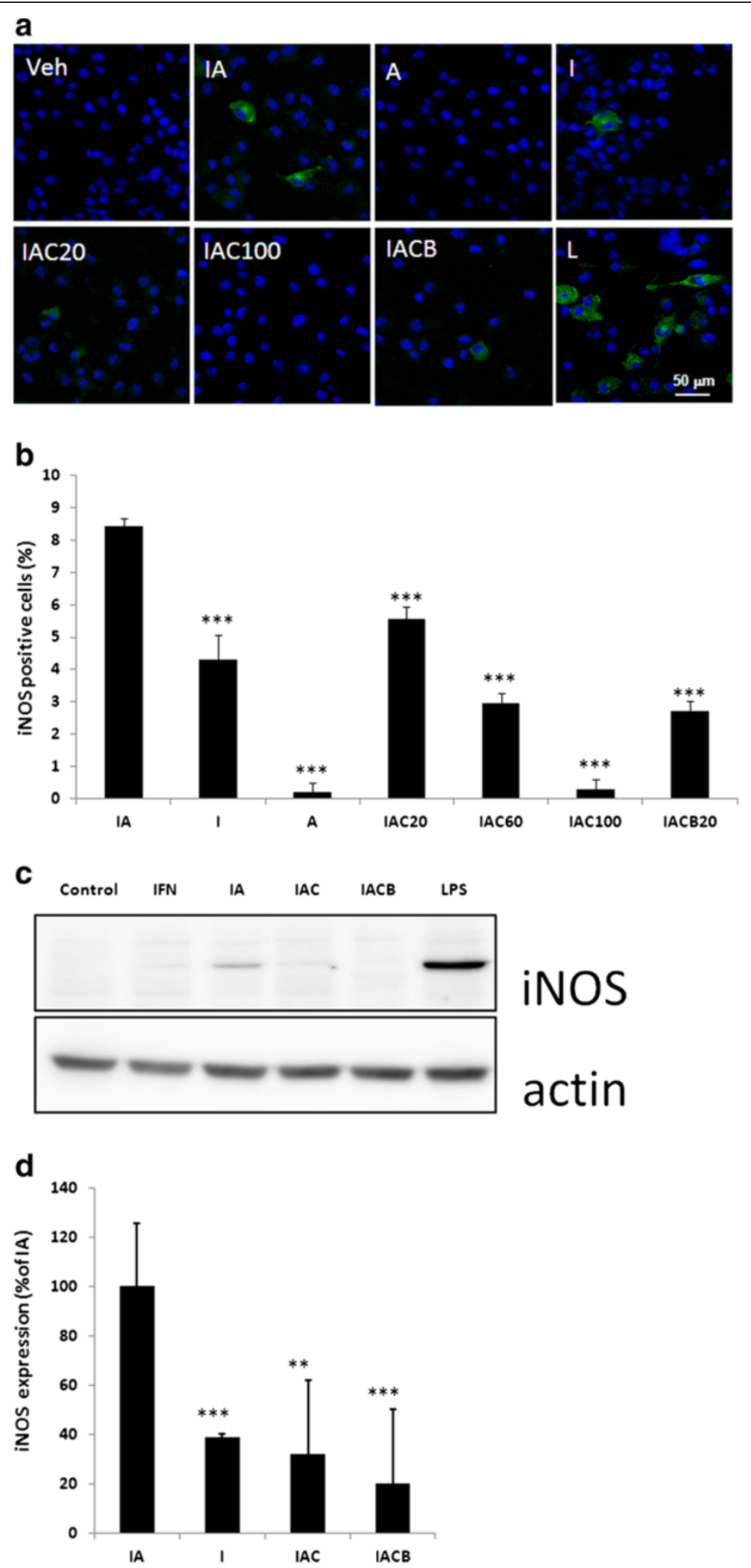

Figure 4 (See legend on next page.) 
(See figure on previous page.)

Figure 4 Effect of Cudrania cochinchinensis on iNOS expression induced by IFN- $\gamma$ combined with fA $\beta$ in BV-2 cells. BV- 2 cell were treated with $0.2 \mathrm{ng} / \mathrm{ml}$ IFN- $\gamma(\mathrm{I}), 1 \mu \mathrm{M} f A \beta(A), I F N-\gamma$ combined with $f A \beta$ (IA). Alternatively, BV-2 cell were treated with $20 \mu \mathrm{g} / \mathrm{ml} \mathrm{CC}-\mathrm{EW}$ (IAC) or $20 \mu \mathrm{M}$ CCB (IACB) for $2 \mathrm{~h}$, and then were treated with IFN- $\gamma$ combined with $\mathrm{fA} \beta$ for $24 \mathrm{~h}$. Cell treated with $10 \mathrm{ng} / \mathrm{ml} \mathrm{LPS}(\mathrm{L})$ was used as positive control. (a) Cells were fixed, subjected to iNOS staining by anti-iNOS antibody (green) and nucleus staining using Hoechst 33258 (blue). (b) The levels of iNOS positive cells (\%) are total count from three different fields. (c) The level of iNOS in cell lysate was determined by immunoblotting using $\beta$ actin as internal standard. (d) The relative level of iNOS in cell lysate exhibited as percentage of that in IA. Results are means \pm S.D. from three independent experiments. Significant differences between the IA and the other treatments are indicated by ${ }^{* *}, \mathrm{p}<0.001$.

beneficial on neuronal survival after the insult of $A \beta[21]$, which may be further developed into therapeutic medicine for $\mathrm{AD}$.

In the present study, we demonstrated that the components of C. cochinchinesis (CC-EW and its six pure isolated compounds) attenuates the fA $\beta$-mediated proinflammatory activation of the IFN- $\gamma$-primed BV- 2 cells, prevents oA $\beta$-mediated activation that was defined by the morphological alteration, and promotes $A \beta$ clearance by glia-dependent phagocytosis and/or proteolysis in the primary mixed glial culture. It has been indicated previously that $\mathrm{oA} \beta$ possesses the ability to stimulate nitric oxide production from the activated BV-2 cells [22] or primary microglia [23]. Furthermore, it has been suggested that $\mathrm{oA} \beta$ and $\mathrm{fA} \beta$ stimulate differential activation on primary microglia [24], since $\mathrm{oA} \beta$ is a stronger M1inductor than $\mathrm{fA} \beta$ [25]. Alternatively, the functional genomics approach has indicated that $A \beta$ may activate BV-2
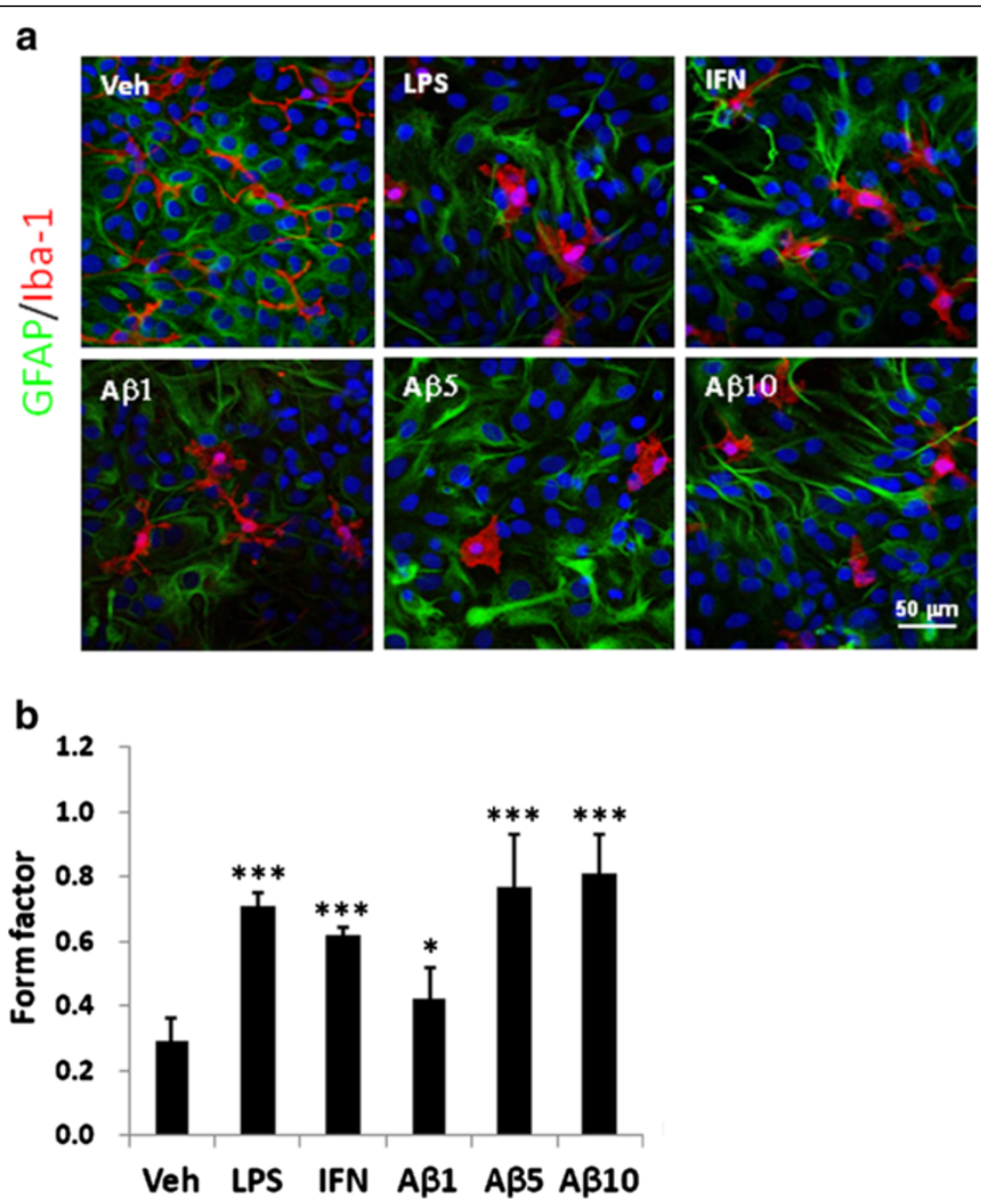

Figure 5 Morphological alteration of the microglia stimulated by LPS, IFN- $\gamma$, oA $\beta$ alone or combined with IFN- $\gamma$. Glial cells treated with

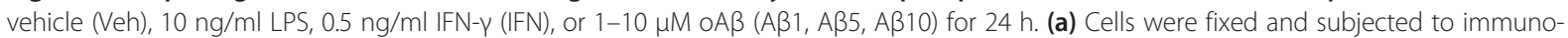
staining of microglia by anti-lba1 antibody (red), astrocyte by anti-GFAP antibody (green) and nuclei staining using Hoechst 33258 (blue). Results are repeated for three times, and represent photographs are shown. (b) Form factor of microglial morphology were calculated as describe in the Method section. Results are means \pm S.D. from three independent experiments and total nine cells of each group were analyzed. Significant differences between the cells treated with vehicle and the other treatments are indicated by ${ }^{*}, p<0.05,{ }^{* *}, p<0.001$. 


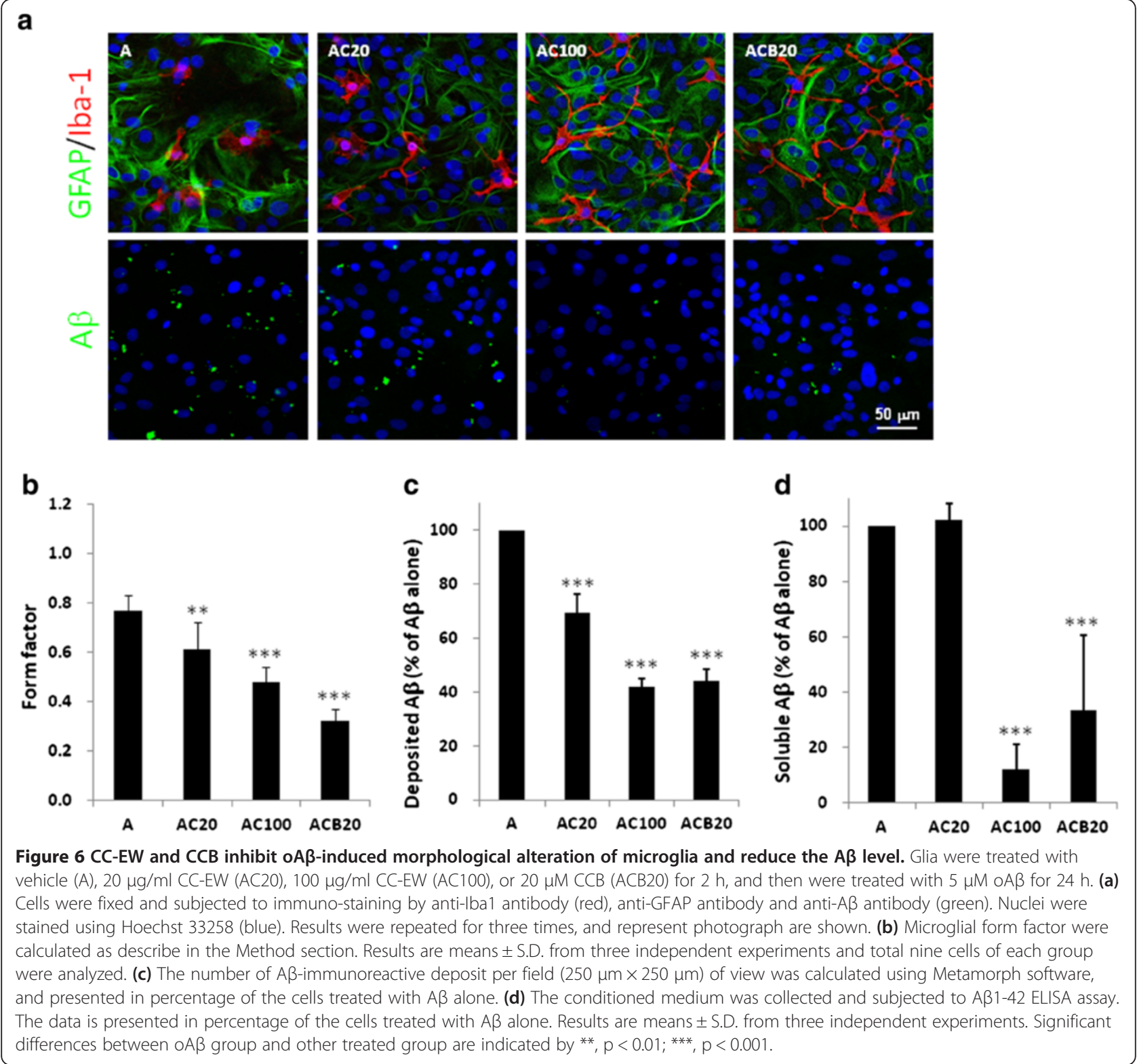

cells to induce several gene expressions that did not include iNOS [26]. In our study, fA $\beta$ or oA $\beta$ alone failed to activate BV-2 cells to produce nitric oxide. The potential reasons for this could be attributed to $\mathrm{AA} \beta$ may only activate the IFN- $\gamma$-primed microglia [8,27]. In our present results, $f A \beta$, but not $o A \beta$, enhanced the nitric oxide production through the promotion of iNOS expression in the IFN- $\gamma$-primed BV-2 cells. The failure of $\mathrm{oA} \beta$ to activate IFN- $\gamma$-primed BV-2 cells may be due to oA $\beta$ as more accessible than $\mathrm{AA} \beta$ to microglial phagocytosis [28] and/or the enzymatic degradation mediated by IDE by BV-2 cells [29].

CCA (1,3,5-trihydroxy-4-prenylxanthone), CCB (1,3,7trihydroxy-4-prenylxanthone), and other four flavonoids were found to inhibit nitric oxide production. In another recent study, 1,3,5-trihydroxy-4-prenylxanthone has been showed to repress LPS-induced iNOS expression in RAW264.7 macrophage via impeding posttranslational modification of interleukine-1 receptor-associated protein kinase 1 (IRAK-1) [2]. LPS selectively bind to toll-like receptors 4 , which have been suggested to be required for $\mathrm{fA} \beta$ to stimulate microglial activation. Therefore, CCA and $C C B$ may also repress $\mathrm{AA} \beta$-induced iNOS expression in the IFN- $\gamma$ primed BV-2 cells via impeding posttranslational modification of IRAK-1. Moreover, luteolin has been suggested to trigger global changes in the microglial transcriptome leading to a unique anti-inflammatory and neuroprotective phenotype in BV-2 cells [30]. In our study, four flavonoids inhibited nitric oxide production, which may be accomplished via a similar pathway. 
Microglia in the healthy mature CNS has a ramified morphology with a small soma and some fine cellular processes [3]. This typical appearance has been associated with microglial "resting" state. Upon different stimuli, the ramified resting microglia can be transferred into distinct activation phenotypes including the ramified alternative activation phenotype and the amoeboid classical activation phenotype [3]. Since the morphological change of microglia has been shown to link the functional phenotypes, the ramified morphology was maintained [5]. Nevertheless, in vitro studies on ramified microglia have been hampered because the morphology of the isolated microglia was amoeboid rather than ramified. Several studies have shown that astrocytes play a significant role in the differentiation and transformation of microglia. The amoeboid microglia has been shown to become ramified when cultured on monolayers of astrocytes [31]. Therefore, the ramified microglia in the mixed glial culture was employed in the present study. Based on our results, LPS, IFN- $\gamma$, and $\mathrm{oA} \beta$ significantly activate the microglia in the mixed glial culture and CC-EW; and CCB prevented the oA $\beta$-mediated morphological transformation from ramified to amoeboid. Interestingly, LPS, IFN- $\gamma$, and oA $\beta$ induced an un-uniformed morphological transformation of astrocytes, which is not comparable with the reactive astrocytes in vivo.

Previous studies have indicated that modulation of microglial receptor may enhance microglial $A \beta$ phagocytosis while suppressing bystander damage to neurons from $A \beta$ activated microglia [32]. Therefore, we hypothesize that aggregated $\mathrm{A} \beta$ stimulates the beneficial microglial phagocytic response and neurotoxic glial innate immune response. As the microglial phagocytosis fails to remove aggregated $A \beta$, the prolonged innate immune response becomes neurotoxic. This model of $\mathrm{AD}$ pathogenesis implies that stimulated microglia enhances $A \beta$ clearance and suppressed microglial activation to prevent bystander damage to neurons will be a potential therapeutic.

\section{Conclusions}

CC-EW and CCB effectively reduced the level of nitric oxide and iNOS stimulated by IFN- $\gamma$ combined with $\mathrm{fA} \beta$. On the other hand, oA $\beta$ alone effectively activated microglia in the mixed glial culture that defined by the morphological change from ramified to amoeboid. CCEW and $C C B$ effectively recovered the $A \beta$-mediated morphological change of microglia and decreased the level of deposited and soluble $A \beta$ by promoting its clearance. Taken together, CC-EW and CCB have potential for therapeutic intervention of $\mathrm{AD}$.

\section{Abbreviations}

$A \beta$ : Amyloid $\beta$ protein; AD: Alzheimer's disease; BSA: Bovine serum albumin; CC-EW: Ethanol/water extracts of Cudrania cochinchinensis; CNS: Central nervous system; DMEM: Dulbecco's Modified Eagle's Medium; fAß: Fibrillary
A $\beta$; IDE: Insulin degrading enzyme; FBS: Fetal bovine serum; IFN- - : Interferon$Y$; iNOS: Inducible nitric oxide synthase; IRAK-1: Interleukin-1 receptorassociated protein kinase 1; LPS: Lipopolysaccharide; M-CSF: Macrophage colony-stimulating factor; $O A \beta$ : Oligomeric $A \beta$.

\section{Competing interests}

The authors declare that they have no competing interests.

\section{Authors' contributions}

CJ carried out the cell line culture and participated in the drafted the manuscript. CC carried out the herbal extraction, purification, and identification. HJ participated in the drafted the manuscript. FY carried out the primary mixed-glial culture and performed the statistical analysis. MF carried out the amyloid preparation and identification. YJ conceived of the study, participated in its design and coordination, and helped to draft the manuscript. All authors read and approved the final manuscript.

\section{Acknowledgements}

This study was supported by Grant NSC-97-2320-B-077-003-MY3 from National Science Council, Grant NRICM-98-DBCM-06 from National Research Institute of Chinese Medicine, Taiwan, and the Ministry of Education-Aim for the Top University Plan (010 AC-B5).

\section{Author details}

'Division of Geriatrics, Cheng Hsin General Hospital, Taipei, Taiwan. ${ }^{2}$ Department of Biotechnology, HunKuang University, Taichung 433, Taiwan. ${ }^{3}$ Institute of Neuroscience and Brain Research Center, National Yang-Ming University, Taipei 112, Taiwan. ${ }^{4}$ Institute of Biopharmaceutical Science, National Yang-Ming University, Taipei 112, Taiwan. ${ }^{5}$ Division of Basic Chinese Medicine, National Research Institute of Chinese Medicine, Taipei 112, Taiwan.

Received: 30 January 2013 Accepted: 31 July 2013

Published: 2 August 2013

\section{References}

1. Fukai T, Oku Y, Hou AJ, Yonekawa M, Terada S: Antimicrobial activity of hydrophobic xanthones from Cudrania cochinchinensis against Bacillus subtilis and methicillin-resistant Staphylococcus aureus. Chem Biodivers 2004, 1:1385-1390.

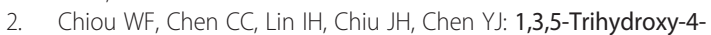
prenylxanthone represses lipopolysaccharide-induced iNOS expression via impeding posttranslational modification of IRAK-1. Biochem Pharmacol 2011, 81:752-760.

3. Alliot F, Lecain E, Grima B, Pessac B: Microglial progenitors with a high proliferative potential in the embryonic and adult mouse brain. Proc Natl Acad Sci USA 1991, 88:1541-1545.

4. Saijo K, Glass CK: Microglial cell origin and phenotypes in health and disease. Nat Rev Immunol 2011, 11:775-787.

5. Nimmerjahn A, Kirchhoff F, Helmchen F: Resting microglial cells are highly dynamic surveillants of brain parenchyma in vivo. Science 2005, 308:1314-1318.

6. Jimenez S, Baglietto-Vargas D, Caballero C, Moreno-Gonzalez I, Torres M, Sanchez-Varo R, Ruano D, Vizuete M, Gutierrez A, Vitorica J: Inflammatory response in the hippocampus of PS1M146L/APP751SL mouse model of Alzheimer's disease: age-dependent switch in the microglial phenotype from alternative to classic. J Neurosci 2008, 28:11650-11661.

7. Venneti S, Wiley CA, Kofler J: Imaging microglial activation during neuroinflammation and Alzheimer's disease. J Neuroimmune Pharmacol 2009, 4:227-243

8. Li M, Pisalyaput K, Galvan M, Tenner AJ: Marcrophage colony stimulatory factor and interferon-gamma trigger distinct mechanisms for augmentation of beta-amyloid-induced microglia-mediated neurotoxicity. J Neurochem 2004, 91:623-633.

9. Farfara D, Lifshitz V, Frenkel D: Neuroprotective and neurotoxic properties of glial cells in the pathogenesis of Alzheimer's disease. $J$ Cell Mol Med 2008, 12:762-780.

10. Streit WJ: Microglia and Alzheimer's disease pathogenesis. J Neurosci Res 2004, 77:1-8.

11. Querfurth HW, LaFerla FM: Alzheimer's disease. N Engl J Med 2010, 362:329-344. 
12. Nakajima K, Honda S, Tohyama Y, Imai Y, Kohsaka S, Kurihara T: Neurotrophin secretion from cultured microglia. J Neurosci Res 2001, 5:322-331.

13. Lee CY, Landreth GE: The role of microglia in amyloid clearance from the AD brain. J Neural Transm 2010, 117:949-960.

14. Yang CN, Shiao YJ, Shie FS, Guo BS, Chen PH, Cho CY, Chen Y, Huang JFL, Tsay HJ: Mechanism mediating oligomeric Abeta clearance by naïve primary microglia. Neurobiol Dis 2011, 42:221-230.

15. Tundo G, Ciaccio C, Sbardella D, Boraso M, Viviani B, Coletta M, Marini S: Somatostatin modulates insulin-degrading-enzyme metabolism: implications for the regulation of microglia activity in AD. PLoS One 2012, 7:e34376.

16. Giulian D, Baker TJ: Characterization of amoeboid microglia isolated from developing mammalian brain. J Neurosci 1986, 6:2163-2178.

17. Chromy BA, Nowak RJ, Lambert MP, Viola KL, Chang L, Velasco PT, Jones BW, Fernandez SJ, Lacor PN, Horowitz PC, Finch E, Krafft GA, Klein WL: Selfassembly of Abeta (1-42) into globular neurotoxins. Biochemistry 2003, 42:12749-12760

18. Dahlgren KN, Manelli AM, Stine WB Jr, Baker LK, Krafft GA, LaDu MJ: Oligomeric and fibrillar species of amyloid-beta peptides differentially affect neuronal viability. J Biol Chem 2002, 277:32046-32053.

19. Huang WC, Yen FC, Shiao YJ, Shie FS, Chan JL, Yang CN, Sung YJ, Huang FL, Tsay HJ: Enlargement of Abeta aggregates through chemokinedependent microglial clustering. Neurosci Res 2009, 63:280-287.

20. Heppner FL, Roth $\mathrm{K}$, Nitsch R, Hailer NP: Vitamine E induces ramification and down regulation of adhesion molecules in cultured microglial cells. Glia 1998, 22:180-188.

21. Lim GP, Chu T, Yang F, Beech W, Frautschy SA, Cole GM: The curry spice curcumin reduces oxidative damage and amyloid pathology in an Alzheimer transgenic mouse. J Neurosci 2001, 21:8370-8377.

22. Shukla SM, Sharma SK: Sinomenine inhibits microglial activation by $A \beta$ and confers neuroprotection. J Neuroinflamm 2011, 8:117.

23. Maezawa I, Zimin PI, Wulff H, Jin LW: Amyloid-beta protein oligomer at low nanomolar concentrations activates microglia and induces microglial neurotoxicity. J Biol Chem 2011, 286:3693-3706.

24. Sondag CM, Dhawan G, Combs CK: Beta amyloid oligomers and fibrils stimulate differential activation of primary microglia. J Neuroinflamm 2009, 6:1.

25. Michelucci A, Heurtaux T, Grandbarbe L, Morga E, Heuschling P. Characterization of the microglial phenotype under specific proinflammatory and anti-inflammatory conditions: Effects of oligomeric and fibrillar amyloid- $\beta$. J Neuroimmunol 2009, 210:3-12.

26. Gan L, Ye S, Chu A, Anton K, Yi S, Vincent VA, von Schack D, Chin D, Murray J, Lohr S, Patthy L, Gonzalez-Zulueta M, Nikolich K, Urfer R: Identification of Cathepsin $B$ as a mediator of neuronal death induced by Abetaactivated microglial cells using a functional genomics approach. J Biol Chem 2004, 279:5565-5572.

27. Twig G, Graf SA, Messerli MA, Smith PJS, Yoo SH, Shirihai OS: Synergistic amplification of $\beta$-amyloid- and interferon- $\gamma$-induced microglial neurotoxic response by the senile plaque component chromogranin $\mathrm{A}$. Am J Physiol Cell Physiol 2005, 288:169-175.

28. Mandrekar S, Jiang Q, Lee CYD, Koenigsknecht-Talboo J, Holtzman DM, Landreth GE: Microglia mediate the clearance of soluble Abeta through fluid phase macropinocytosis. J Neurosci 2009, 29:4252-4262.

29. Qiu WQ, Walsh DM, Ye Z, Vekrellis K, Zhang J, Podlisny MB, Rosner MR, Safavi A, Hersh LB, Selkoe DJ: Insulin-degrading enzyme regulates extracellular levels of amyloid beta-protein by degradation. $J$ Biol Chem 1998, 273:32730-32738.

30. Dirscherl K, Karlstetter M, Ebert S, Kraus D, Hlawatsch J, Walczak Y, Moehle C, Fuchshofer R, Langmann V: Luteolin triggers global changes in the microglial transcriptome leading to a unique anti-inflammatory and neuroprotective phenotype. J Neuroinflamm 2010, 7:3
31. Jones $L L$, Kreutzberg GW, Raivich G: Transforming growth factor $\beta^{\prime} s$ 1, 2 and 3 inhibit proliferation of ramified microglia on an astrocyte monolayer. Brain Res 1998, 795:301-306.

32. Shie FS, Breyer RM, Montine TJ: Microglia Lacking E Prostanoid Receptor Subtype 2 Have Enhanced $A \beta$ Phagocytosis yet Lack $A \beta$-Activated Neurotoxicity. Am J Pathol 2005, 166:1163-1172.

doi:10.1186/1423-0127-20-55

Cite this article as: Wang et al:: Cudrania cochinchinensis attenuates amyloid $\beta$ protein-mediated microglial activation and promotes gliarelated clearance of amyloid $\beta$ protein. Journal of Biomedical Science $201320: 55$

\section{Submit your next manuscript to BioMed Central and take full advantage of:}

- Convenient online submission

- Thorough peer review

- No space constraints or color figure charges

- Immediate publication on acceptance

- Inclusion in PubMed, CAS, Scopus and Google Scholar

- Research which is freely available for redistribution 